\title{
STRUCTURAL AND SEMANTIC CHARACTERISTICS OF PROVERBS
}

\author{
Hilola Musinovna Sotvaldieva
}

Senior Teacher, Faculty Of Foreign Languages, Fergana State University, Uzbekistan

Anar Tadjibaevna Masharipova

Assistant Teacher, Faculty Of Foreign Languages, Fergana State University, Uzbekistan

\section{ABSTRACT}

This paper is devoted to the analysis of semantic and structural features of some English proverbs. The equivalents of some proverbs in a target language are given for interpreting them in the other language to find out several important innovative ways of translation and contrasting their peculiarities in the English and Uzbek languages. The results and examples of this paper can help to distinguish some differences in the meanings of the English and Uzbek proverbs and to learn some peculiarities of them.

KEYWORDS: - Proverb, cultureme, pragmatics, synonymy, antonymy, equivalent, context.

\section{INTRODUCTION}

A proverb (from the Latin "proverbium" - proverb) is a popularly known, repeated and concrete saying with complete utterance; they express a truth, based on common sense or the practical experience of people. Prominent linguist W. Mieder gives a definition to a proverb in his book: "A proverb is a short, generally known sentence of the folk which contains wisdom, truth, morals, and traditional views in a metaphorical, fixed and memorisable form and which is handed down from generation to generation" [1, p. 27].

It is clear from the definition that proverbs are usually based on metaphor and have figurative meaning. Although several scholars give many definitions for the notion of a proverb, Mieder's definition is considered to be the best one among them. Because proverb is not a simple unit of a language, it is a ready-made sentence that gives metaphorical meaning with words of wisdom or traditional thoughts of people or nation. Besides, they have been created not only by an individual in a short period of time. A proverb is a product of the definite nation as a folk saying during considerable long time. They are handed down through years and ages as frames or models of human life typical situations. Ch. C. Doyle suggests investigating them as minimal folk poems [2, p. 4] in literature, because they enliven dialogues or give expressiveness and emotiveness to poetry or prose in various ways.

Folklore and linguistics study proverbs as their 
CURRENT RESEARCH JOURNAL OF PHILOLOGICAL SCIENCES 2(11):

153-157, November 2021

DOI: https://doi.org/10.37547/philological-crjps-02-11-33

ISSN 2767-3758

(C)2021 Master Journals

Crossref do

gil Google

Accepted $25^{\text {th }}$ November, 2021 \& Published $30^{\text {th }}$ November, 2021

objects. Some scholars (Taylor, Seiler, Firth, Mieder, etc.) mentioned in their works that the main reason of studying proverbs in folklore is their traditionality. No doubt that folklore units are traditional and recurring; as N.R. Norrick points they are "seen as authorless, sourceless and also as non-literary, non-learned" [2, p. 10]. Proverbs own these features but not completely. However, they are also investigated as a folklore unit and differentiate form proverbial phrases, clichés, idioms, aphorisms, wellerisms, superstations, maxims and slogans.

Linguistics also distinguish proverbs form idioms and phrases; besides analyse them as sentences, clauses, conversational turns, speech acts, etc. A Proverb is considered as a phraseological unit with figurative meaning in linguistics and to be equal to a sentence according to a complete utterance that they can form in a speech.

Moreover, their diverse expressiveness and emotiveness are obviously noticed during the process of conversation. Therefore, proverbs can represent the speech situation clearly.

As we know, proverbs, as a rule, are used for some practical, pragmatical purposes in various circumstances of everyday communication. With the aid of a proverb we can aim to provide statements and opinions, forecast something, express doubts, reproach someone with something, accuse someone of something, justify or excuse somebody, warn against something, advise something or interdict somebody from doing something, and so on, and so forth. It is unthinkable to consider the proverb apart from such pragmatic functions[5, p.50].

Unfortunately, paremiologists have so far only some vague ideas of the functions of proverbs. Moreover, the proverb lies just somewhere on the borderlands between language and folklore, and shares its functions with both of them, and one cannot say there is a notable agreement between the conceptions of different authors on the functions of language or folklore. We accept here a more simple and widespread scale, namely the set of three degrees:

Statement $\rightarrow$ evaluation $\rightarrow$ prescription

We suppose, however, this scale should fit in with the nature of the proverb, and it has, incidentally, the virtues that it operates with concepts general enough, and allows to consider the set of its subfunctions (or functional aspects) as a unified system. The functional aspects mentioned are in certain relationship with grammatical moods of the sentence. Hence the illusion may arise that proverbs can be classified functionally straight on the ground of their "superficial" grammatical moods, so that the proverbs with stating (designative, informative) function were represented with indicative sentences, and those with normative (prescriptive, evocative) function, respectively, with imperative sentences. This illusion, however, would be immediately shattered against two complications:

The evaluative, (emotive, expressive) function has no separate or distinct manifestation (or "surface equivalent") in the shape of any grammatical mood. As affirmed by several authorities, every verbal utterance fulfills not only one function, otherwise, a context-free proverb, like any other utterance, is functionally indefinite.

The place of proverbs, sayings and familiar quotations with respect to set expressions is a controversial issue. A proverb is a short familiar epigrammatic saying expressing popular wisdom, a truth or a moral lesson in a concise and, imaginative way.Proverbs have much in common with set expressions because their lexical components are also constant, their meaning is traditional and mostly figurative, and they are introduced into speech ready-made. That is why some scholars 
CURRENT RESEARCH JOURNAL OF PHILOLOGICAL SCIENCES 2(11):

153-157, November 2021

DOI: https://doi.org/10.37547/philological-crjps-02-11-33

ISSN 2767-3758

(C)2021 Master Journals

\section{Crossref do}

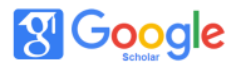

Accepted25th November, 2021 \& Published $30^{\text {th }}$ November, 2021

following V. V. Vinogradov think proverbs must be studied together with phraseological unities. Others like J. Casares and N. N. Amosova think that unless they regularly form parts of other sentences it is erroneous to include them into the system of language because they are independent units of communication. N. N. Amosov even thinks that there is no more reason to consider them as part of phraseology than, for instance, riddles and children's counts. This standpoint is hardly acceptable especially if we do not agree with the narrow limits of phraseology offered by this author[3, p.101].

As to the argument that in many proverbs the meaning of component parts does not show any specific changes when compared to the meaning of the same words in free combinations, it must be pointed out that in this respect they do not differ from very many set expressions, especially those which are emotionally neutral. Another reason why proverbs must be taken into consideration together with set expressions is that they often form the basis of set expressions. For example; the last straw breaks the camel's back: the last straw; a drowning man will clutch at a straw: to clutch at a straw; it is useless to lock the stable door when the steed is stolen: to lock the stable door 'take precautions when the accident they are meant to prevent has already happened'. Both set expressions and proverbs are sometimes split and changed for humorous purposes, as in the following quotation where the proverb" All is not gold that glitters" combines with an allusion to the set expression golden age. It will be an age not perhaps of gold, but at least of glitter.

As to familiar quotations, they are different from proverbs in their origin. They come from literature but by and by they become parcel of the language, so that many people using them do not even know that they are quoting and very few could accurately name the play or passage on which they are drawing even when they are aware of using a quotation from Shakespeare.For example: Something is rotten in the state of Denmark; Brevity is the soul of wit.

Quotations from classical sources were once a recognized feature of public speech "times change, and we change with them", "I fear the Greeks, even when bringing gifts". Now they are even regarded as bad form because they are unintelligible to those without a classical education. So, when a speaker ventures a quotation of that kind he hastens to translate it. A number of classical tags nevertheless survive in educated speech of many countries. There are the well-known phrases, such as for this special reason; "in good faith".

In giving this review of English set expressions we have paid special attention to the fact that the subject is a highly complex one and that it has been treated by different scholars in very different ways. Each approach and each classification have their advantages and their drawbacks. The choice one makes depends on the particular problem one has in view and even so there remains much to be studied in the future. It is likely unreasonable to imagine that the proverb could have its say, about the matters which have no social relevance or topicality, or in situations including no alternatives, or that it could state something with entire indifference, or put forward statements which let no strategic (prescriptive) advices or hints to be derived from them. It also appears to be obvious that a proverb cannot order, interdict, advise anything without qualifiying previously as good or bad (or axiologicaliy irrelevant) either the suggestable or forbiddable activity or attitude itself or something linked to this activity or attitude, e.g., its end, means, degree of intensity, speed, time, place, etc.; and if the proverb puts forward appraisals, these appraisals are, in turn, likely to be founded on some cognized truths, laws and, regularities (or current opinions, beliefs or at least 
CURRENT RESEARCH JOURNAL OF PHILOLOGICAL SCIENCES 2(11):

153-157, November 2021

DOI: https://doi.org/10.37547/philological-crjps-02-11-33

ISSN 2767-3758

(C2021 Master Journals

Crossref do

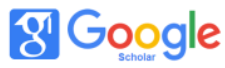

Accepted $25^{\text {th }}$ November, 2021 \& Published $30^{\text {th }}$ November, 2021

prejudices)[7, p.196].

The problem of defining a proverb appears to be as old as man's interest in them. People who consciously used them or began to collect them in antiquity obviously needed to differentiate proverbs from other gnomic devices such as apothegms, maxims, aphorisms, quotations, etc. Jan Fredrik Kindstrand reviewed some of these early definition attempts in his fascinating paper on "The Greek Concept of Proverbs,"

The following tentative typology draws of the material of English proverbs. The classification criteria are as follows:

the "normality" versus the contradictory or "broken" nature of the literal sense of the proverb text;

the presence versus absence of semantic transformation (trope);

the totality versus partiality of the semantic transformation.

Proverbs in traditional English society differ from those of western societies, in that they are a cultural heritage of the lower class of society and therefore they are not shared by the upper class, who had for their cultural vehicle form of vernacular language. Though there are some proverbs borrowed from other languages, the majority of English proverbs were made by the common people as lessons and guidelines of life for themselves.

Proverbs often have scatological and abusive references, reflecting the crude and uncouth pattern of life. The common people used the proverbs to describe the inner " thoughts of their hardship, to warn against the dangers of life, to vent their grievance against the oppressions of the ruling upper class, and to express the joys of life. In short the proverbs disclose most revealingly the realities of lower class life. The proverbs in this sense function as important social documents. What is mirrored in these proverbs show how poor the common people were who these poor vulgar people were, how they struggled to survive in tough circumstances, and what their philosophy of life was. These are random selections from English proverbs which typically portray the life of the common people. They show a picture of a poor man, who does not like rich men, and who hates the noble, ruling' class. Although he is always victimized, he is secretly longing for the days when he can have his revenge.

English proverbs which are part of traditional culture lose their conventional significance. The proverb used to be a form of collective' consciousness and has evolved in its language based on traditional experiences. Transmission of proverbs was an essential part of culture and a prerequisite for education and the formation of self. Those past proverbs, however, have been driven away from education. What is more, the proverb is even on the verge of extinction. The proverb has been left as mere information which is individualistic, but not imperative or social at all.

\section{REFERENCES}

1. Mieder W. International Proverb Scholarship. New York: Garland Publishing, 1993. P.

2. Gotthardt H.H., Varga M.A. (eds.) Introduction to Paremiology: A Comprehensive Guide to Proverb Studies. Berlin: DeGruyter, 2014. P. 210.

3. Амосова Н. Н. «Основы английской фразеологии». - Л.: ЛГУ, 1963.

4. Арнольд И. В. «Структура и семантика предложений и текста в германских языках».-Л., 1987.

5. Ашурова Д. У. Производное слово в свете коммуникативной теории языка Т. , Фан, 1991

6. Abdullaeva N.E. Semantic and linguocultural features of English and Uzbek proverbs with concept of friendship // Problems of Modern 
CURRENT RESEARCH JOURNAL OF PHILOLOGICAL SCIENCES 2(11):

153-157, November 2021

DOI: https://doi.org/10.37547/philological-crjps-02-11-33

ISSN 2767-3758

(C)2021 Master Journals

7 Crossref dol 81 Google

Accepted25 $5^{\text {th }}$ November, 2021 \& Published 30 $0^{\text {th }}$ November, 2021

Science and Education, 2017. № 7 (89).

7. Karamatova K.M., Karamatov X.S. Proverbs, maqollar, пословицы. -Toshkent: Mehnat, 2001. 